\title{
EVALUATION OF ANTIMICROBIAL POTENTIAL OF NIGELLA SATIVA OIL IN A MODEL FOOD MATRIX
}

\author{
MARA GEORGESCU ${ }^{1 \# *}$, PAUL RODIAN TĂPĂLOAGA $\breve{~}^{1 \#}$, DANA TĂPĂLOAGA $\breve{1}^{1 \#}$, FLORIN \\ FURNARIS $^{1 \#}$, OCTAV GINGHINA ${ }^{2 \#}$, CAROLINA NEGREI ${ }^{2 \#}$, CARMEN GIUGLEA $^{2 \#}$, \\ CRISTIAN BĂLĂLĂU ${ }^{2 \#}$, EMIL ȘTEFĂNESCU ${ }^{2 \#}$, IOANA ANDREEA POPESCU ${ }^{2 *}$, DRAGOȘ \\ GEORGESCU ${ }^{2 \#}$
}

${ }^{1}$ University of Agronomic Sciences and Veterinary Medicine of Bucharest, 59 Mărăşti Boulevard, Bucharest, 011464, Romania

${ }^{2}$ University of Medicine and Pharmacy "Carol Davila" Bucharest, 37 Dionisie Lupu Street, Bucharest, Romania

*corresponding author:dr_georgescu_mara@yahoo.com

\#Authors with equal contribution.

Manuscript received: October 2018

\begin{abstract}
Nigella sativa (black cumin) is known for its antibacterial activity. However, available literature does not sufficiently explore the possible interactions with the natural wild microflora in complex food matrices. This study is using as model food matrix, a traditionally manufactured cheese, without additives, without starter cultures and without pathogen culture, to study the antimicrobial effect of Nigella sativa seed oil (NSSO), as well as the physicochemical properties of this food matrix during the study. The experiment included three batches of food matrix: control batch without NSSO, $0.1 \%$ and $0.2 \% \mathrm{w} / \mathrm{w}$ NSSO enriched batch. Natural occurring E.coli, coliforms and Staphylococcus spp. were significantly inhibited by NSSO. Total bacterial count (APC) registered significant improvement during the experiment. The antimicrobial activity of NSSO proved selective, as no significant effect was seen on the beneficial LAB. NSSO significantly improved the sensory qualities of the food matrix samples. NSSO kept significant selective antimicrobial effect when used with a complex food matrix, without altering the physicochemical properties of this food matrix, suggesting that NSSO could be a natural antibiotic candidate that could be used as food dietary supplement.
\end{abstract}

\section{Rezumat}

Nigella sativa (chimenul negru) este cunoscut pentru activitatea antimicrobiană. $\mathrm{Cu}$ toate acestea, literatura științifică disponibilă până în prezent, nu aprofundează interacțiunile cu flora microbiană naturală a substraturilor alimentare complexe. Studiul de față utilizează ca model de substrat alimentar, un sortiment de brânză tradițională, obținută fără aditivi, fără culturi starter şi neadiționată experimental cu germeni patogeni, pentru a studia efectul antimicrobian al uleiului semințelor de Nigella sativa (NSSO), precum şi proprietățile fizico-chimice ale substratului alimentar pe parcursul studiului. Experimentul a constat în utilizarea a trei loturi de substrat alimentar experimental: lotul de control, fără NSSO, și loturile îmbogățite cu $0,1 \%$ și respectiv, $0,2 \% \mathrm{~m} / \mathrm{m}$ NSSO. Tulpinile sălbatice de E. coli, coliformi și Staphylococcus spp. au fost semnificativ inhibate pe durata experimentului. Numărul total de germeni a înregistrat îmbunătățire semnificativă sub influența NSSO pe durata experimentului. Activitatea antimicrobiană a NSSO a fost selectivă, întrucât tulpinile de bacterii acido-lactice benefice nu au fost inhibate. NSSO a îmbunătățit calitățile organoleptice ale substratului alimentar utilizat. NSSO a menținut efectul antimicrobian la utilizarea împreună cu un substrat alimentar, fără a altera proprietățile fizico-chimice ale acestuia, sugerând faptul că NSSO ar putea fi un candidat antibiotic natural, care poate fi utilizat ca supliment alimentar.

Keywords: Nigella sativa, antimicrobial activity, food matrix, dietary supplement

\section{Introduction}

The antimicrobial resistance of pathogens remains a major problem for the public health, as multi-resistant isolates of opportunistic and pathogenic microorganisms are rapidly spreading [17, 21, 23, 27, 32, 33, 54, 62, 65]. The scientific community has been targeting in vitro and in vivo studies of antimicrobial effects of various natural compounds, as alternatives to conventional therapy, or as prophylactic solutions [38]. A continuous search of antimicrobial solutions against various pathogens, adequate as natural additives in foods, has increasingly been reported by recent studies [5, 6, 28, 30, 40, 49, 70, 73, 76].

Nigella sativa is known for various beneficial effects, among which the antibacterial activity was extensively studied, either as possible development of pharmacological remedies or as food additive. Black cumin seeds have been extensively used as spices in a wide range of foods and beverages especially in Middle and Far East countries, being appreciated for a wide range of pharmacological actions, such as antidiabetic, anticancerous, immunity modulator, analgesic, antimicrobial, anti-inflammatory, spasmolytic, broncho- 
FARMACIA, 2018, Vol. 66, 6

dilator, antioxidant etc. [3, 25, 39, 67]. Most of Nigella sativa therapeutic properties have been attributed to thymoquinone, considered the most significant bioactive component of the essential oil [48]. Nigella sativa is commonly added to food, as seeds [41] or essential oil [2, 46, 59], for various beneficial effects. Recent literature provides studies of Nigella sativa seeds or cold pressed oil effects on the overall quality of various foods [4, 22, 45, 55, 72]. The antimicrobial effects of Nigella sativa have extensively been studied in vitro $[15,16,29,31,43,60,74]$ and in vivo [66] against various microorganisms such as Streptococcus, Enterobacteriaceae, Staphylococcus, Salmonella, Helicobacter, Listeria, Pseudomonas, Clostridium, Klebsiella, Proteus etc. However, available literature does not provide sufficient information to the unknown interactions with the natural wild microflora in complex food matrices, which undergo under ripening [1]. The antimicrobial activity of Nigella sativa is influenced by the complex microbiological and physicochemical processes which take place in food matrices. Most of the studies focus on experimental food matrices inoculated with starter cultures (lactic acid bacteriaLAB), but also with pathogenic bacteria cultures, in various concentrations, used for evaluating the antimicrobial effect of Nigella sativa. For example, in our previous research [37], considerable reduced counts of Staphylococcus aureus, Listeria monocytogenes, E. coli and Salmonella enteritidis were revealed for $0.1-1 \% \mathrm{w} / \mathrm{w}$ NSSO enriched food matrix, when compared to control.

Each type of food matrix is considered a unique microbial ecosystem, which requires an individual approach, as indicated by numerous literatures references [19, 34, 36, 61, 68, 69, 77]. Therefore, this study is proposing a new approach in investigating the potential antimicrobial effect of Nigella sativa seed oil (NSSO), by using as food matrix, a model of traditionally manufactured cheese, without addition of starter cultures and by using only the natural contaminating microflora.

\section{Materials and Methods}

Nigella sativa cold pressed seed oil. Nigella sativa (black cumin) cold pressed seed oil $\left(\mathrm{Negriol}^{\circledR}\right)$ was purchased from a company in Romania, Aghoras Invent SRL, Bucharest.

Food matrix used for antimicrobial testing. For experimental production of the food matrix, milk received at processing unit was checked for titratable acidity (between $16-19^{\circ} \mathrm{T}$ ), fat content and temperature $\left(4-8^{\circ} \mathrm{C}\right)$. The fat content of raw milk was standardized to $4 \%$, leading to $45 \%$ fat in dry matter $(\% \mathrm{FDM})$ in final food matrix. The average experimental cheese yield from milk was $12-15 / 100 \mathrm{~L}$. Milk was received refrigerated $\left(4-8^{\circ} \mathrm{C}\right)$ and heated mildly at $30-35^{\circ} \mathrm{C}$. No starter culture was used before curdling and there was no addition of calcium chloride, the milk being used raw, with natural lactic acid bacteria content. The experiment included three batches of food matrix: control cheese without NSSO, $0.1 \%$ $\mathrm{w} / \mathrm{w}$ NSSO enriched cheeses and $0.2 \% \mathrm{w} / \mathrm{w}$ NSSO enriched cheeses. The NSSO was added to the mildly heated milk in the respective concentrations, before renneting. The content of the Ideal ${ }^{\circledR}$ rennet dose $(8 \mathrm{~g})$ was diluted in $250 \mathrm{~mL}$ warm distilled water and $25 \mathrm{~mL}$ solution were added to $10 \mathrm{~L}$ warm milk $\left(30-35^{\circ} \mathrm{C}\right)$, under continuous manual mixing for 10 minutes. Coagulation time was 30 - 45 minutes. The soft curd was left for further solidification needed for processing, for 15 - 30 minutes. All previous, as well as further stages of food matrix obtaining, were followed according to the usual, traditional brined cheese manufacturing [71]. The soft curd is processed through repeated pressing and cutting into pieces until left resting for 20 minutes before cutting to final size cubes $(12 / 12 \mathrm{~cm})$. The brine concentration was $6-8 \%$. Brining was performed at maximum $16^{\circ} \mathrm{C}$, for 24 hours and was followed by drying for 12 hours at $2-8^{\circ} \mathrm{C}$ on wood shelves. Experimental food matrix samples were packed in vacuumed plastic bags and kept refrigerated $\left(4-8^{\circ} \mathrm{C}\right)$ for 42 days.

Microbiological analysis. E. coli and coliforms enumeration was performed using $3 \mathrm{M}^{\mathrm{TM}}$ Petrifilm $^{\mathrm{TM}}$ E. coli/Coliform Count Plate (Petrifilm ${ }^{\mathrm{TM}}$ EC, St. Paul, Minnesota, USA). Plating, incubation and interpretation (counting on standard colony counter) were performed according to AOAC Official Methods for total coliforms [13]. Staphylococcus aureus enumeration was performed using $3 \mathrm{M}^{\mathrm{TM}}$ Petrifilm ${ }^{\mathrm{TM}}$ Staph Express Count System (St. Paul, Minnesota, USA) and Petrifilm Staph Express disk [8]. Lactic acid bacteria (LAB) isolation was performed using Rogosa agar (Difco ${ }^{\mathrm{TM}}$ Rogosa SL Agar) and incubation in Petri dish at $35 \pm$ $2^{\circ} \mathrm{C}$ for 48 hours in $\mathrm{CO}_{2}$ gas pack system (using BBL Gas Pak $\mathrm{CO}_{2}$, BD 270308). This medium is specific for Lactobacillus spp. [24]. Total aerobic plate count (APC) was performed using the $3 \mathrm{M}$ Petrifilm ${ }^{\mathrm{TM}}$ Aerobic Plate Count System (St. Paul, Minnesota, USA) [11].

Physicochemical analysis. Experimental food matrix samples were analysed in duplicates for moisture, fat, protein contents, at $0,14,28,35$ and 42 days of ripening, according to the AOAC Official Methods of Analysis [9, 10, 12]. Titratable acidity of the sample was determined using the AOAC Official Methods of Analysis [14]. The pH of samples was measured by electrometric method using two measuring devices: the Fisher Scientific Accumet Basic pHmeter, used directly by insertion in the sample and the InoLab $\mathrm{pH} 740 \mathrm{pH} /$ meter, used for measuring the $\mathrm{pH}$ of processed sample. The water suspension $(1 \mathrm{~g} / 10 \mathrm{~mL}$ bidistilled water) of the sample was homogenised using the Homogenizer Gas-Col ${ }^{\mathrm{TM}}$ at $4000 \mathrm{rpm}$ and 
then centrifuged using the Sigma $2 \mathrm{~K} 15$ centrifuge, for $10-15$ minutes at $4^{\circ} \mathrm{C}$. The supernatant was used for $\mathrm{pH}$ measurement. The $\mathrm{pH}$ values were expressed as average of the two readings.

Sensory evaluation. Sensory analysis of the experimental cheese samples was performed according to the descriptive sensory analysis method $[50,52]$. The analysis was performed by a panel of 10 assessors, all medical doctors with no experience in cheese sensory evaluation, in order to express the impressions of regular consumers. The samples were assessed for flavour, body and texture, appearance and overall quality right after processing, at 14, 28 and 42 days of ripening. These attributes were awarded different ratios in the total score of the sample: overall quality $40 \%$, flavour $30 \%$, body and texture $20 \%$ and appearance $10 \%$. All individual attributes were scored according to the 10 points hybrid hedonic scale $(0=$ dislike extremely, $5=$ neither liked, nor disliked, $10=$ like extremely), because it is easier to be used by untrained assessors in comparison the classical 9-point hedonic scale [64].

Data analysis. For the physicochemical testing, each sample was in duplicates. For the sensory evaluation, data from 10 panellists was averaged \pm standard deviation. Data analysis was performed by One way analysis of variance (ANOVA) using SAS [7]. The threshold of significance level was $p<0.05$. The repetitions of determinations were not considered in statistical significance calculations.

\section{Results and Discussion}

Antimicrobial effect of NSSO against naturally occurring E. coli, coliforms, in the model food matrix The supplementation with NSSO revealed significant antibacterial action against $E$. coli (the f-ratio value is 3.93321; the p-value is 0.042335 ; the result is significant at $\mathrm{p}<0.05$ ), after one week of ripening, as indicated by the results of enumeration performed in control cheeses compared with NSSO enriched cheese samples (Figure 1). The average $\log \mathrm{CFU} / \mathrm{g}$ throughout ripening was $3.69 \pm 0.3571$ for control cheeses, while for $0.1 \%$ $\mathrm{w} / \mathrm{w}$ and $0.2 \% \mathrm{w} / \mathrm{w}$ NSSO samples it was $3.26 \pm$ 0.505 and $2.87 \pm 0.6197$, respectively. Also, there was significant decrease in E. coli population starting from ripening day 7 , throughout the rest of the ripening period (the f-ratio value is 4.50337 ; the p-value is 0.024433 ) in all cheese treatment batches, with the lowest residual contamination value for $0.2 \% \mathrm{w} / \mathrm{w}$ NSSO cheese, of $2.07 \log \mathrm{CFU} / \mathrm{g}$ ' at 42 days of ripening.

The supplementation with NSSO also revealed significant differences (the f-ratio value is 3.61277; the $p$-value is 0.047961 ) in coliforms contamination fluctuation, between the experimental cheeses supplemented with NSSO and the control cheese (Figure 2). However, no significant differences were noticed in terms of antibacterial activity against coliforms, between $0.1 \% \mathrm{w} / \mathrm{w} \mathrm{NSSO}$ and $0.2 \% \mathrm{w} / \mathrm{w}$ NSSO batches (the f-ratio value is 1.82077 ; the pvalue is 0.20213 ), even though the counts were lower throughout ripening for $0.2 \% \mathrm{w} / \mathrm{w}$ NSSO cheeses (Figure 2).

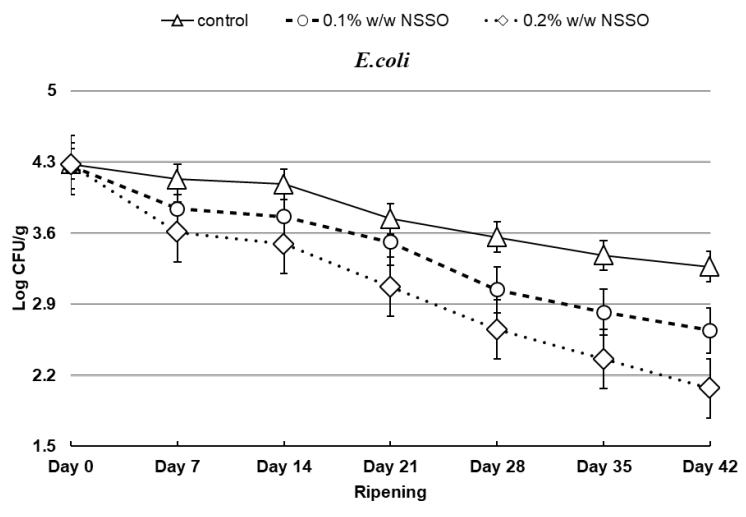

Figure 1.

E. coli count in food matrix samples over 42 days (enriched with $0.1 \%$ and $0.2 \% \mathrm{w} / \mathrm{w} \mathrm{NSSO}$, compared with control cheese)

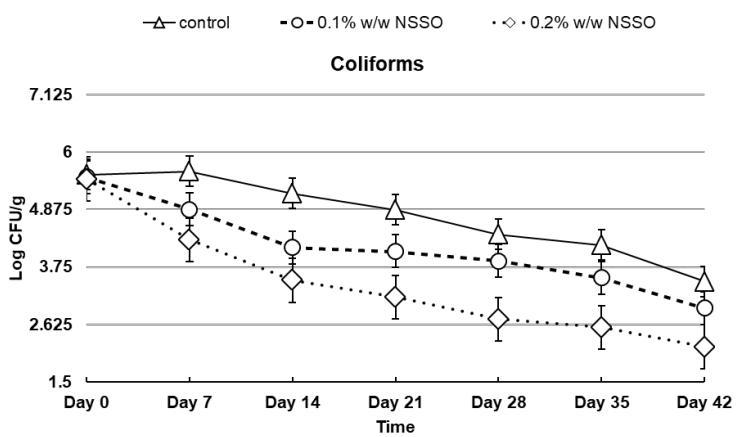

Figure 2.

Coliforms' count in food matrix samples over 42 days (enriched with $0.1 \%$ and $0.2 \% \mathrm{w} / \mathrm{w} \mathrm{NSSO}$, compared with control cheese)

The antibacterial effect of NSSO on E. coli and coliforms was also cited by other recent studies, which revealed in vitro inhibitory action of various extracts and cold pressed oil, against pathogenic strains of $E$. coli, Salmonella, Helicobacter pylori [15]. The overall dropping of E. coli and coliforms' counts during the experiment is consistent with $\mathrm{pH}$ and titratable acidity dynamics, as increased acidity levels prevent multiplication of such pathogens. These results are slightly different from other studies, which report insignificant differences between the rates of $E$. coli and coliforms decrease of the NSSO treated cheeses and control cheeses [24], but resemble other reports indicating $0.1 \%$ and $0.2 \%$ Nigella sativa oil addition has significant effect over E.coli count reduction in cheese [46]. 
Antimicrobial effect of NSSO against naturally occurring Staphylococcus spp. in model food matrix The antimicrobial effect of Nigella sativa oil and extracts on Staphylococcus spp. is extensively cited throughout literature, both in vitro $[29,31,75]$ and in vivo experiments [16, 42, 67]. Also, Staphylococcus spp. is a commonly found contaminant of raw milk cheeses, especially those processed through traditional methods, as revealed in recent studies [51, 57]. As staphylococci can grow at high sodium chloride concentrations, brined cheeses are commonly associated with Staphylococcus contamination from milking and processing environment and personnel, staphylococcal toxins being a frequent cause of foodborne intoxications $[20,47]$. Therefore it was expected to find natural staphylococcal contamination of the food matrix and the revealed counts were not high enough for enterotoxin production (Figure 3). For all cheese samples, Staphylococcus counts dropped starting with the $7^{\text {th }}$ day, after slight, non-significant rising shift during the first 7 days $(p<0.05)$. This may also be correlated with the dropping trend of $\mathrm{pH}$ values in all cheeses, as staphylococcal growth is limited at $\mathrm{pH}$ values below $5.8-6[26]$.

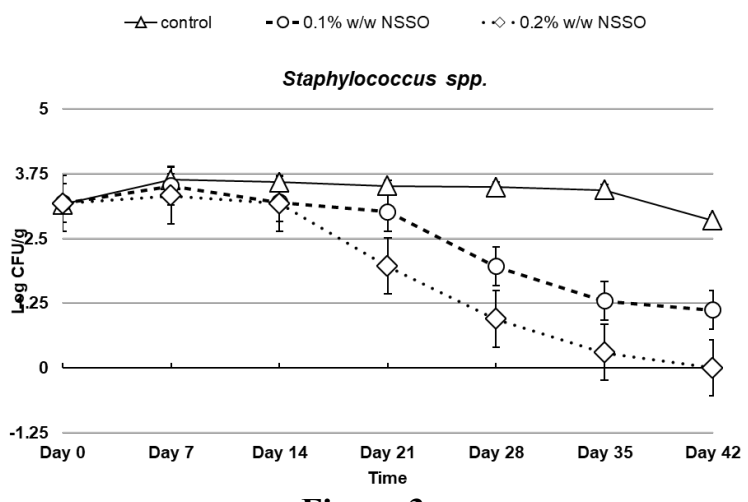

Figure 3.

Staphylococcus spp. count in food matrix samples over 42 days (enriched with $0.1 \%$ and $0.2 \% \mathrm{w} / \mathrm{w}$ NSSO, compared with control cheese)

NSSO was significantly associated with lower staphylococcal counts (the f-ratio value is 4.02393; the p-value is 0.035934 ) than the ones noticed for control samples, throughout the study length (Figure 3). These findings are in agreement with other studies which report significant reducing effect against the proliferation of $S$. aureus by addition of NSSO [46]. Another opinion phrased by similar research states that both $0.1 \%$ and $0.2 \%$ NSSO supplementation induce significantly reduced counts in $S$. aureus and E. coli, but $0.2 \%$ concentration showed the most intense effect [55]. Most authors consider a decrease of $1.3-1.5 \log \mathrm{CFU} / \mathrm{g}$, by the $21^{\text {st }}$ day, as being significant [46]. This study analysed the degree of significance in terms of difference in count dynamics between treatment groups and control, throughout the study, as this comparison was considered useful for assessing the impact of NSSO on natural contaminating microflora in regular ripening conditions and not the antimicrobial capacity of Nigella sativa seed oil on its own.

Antimicrobial effect of NSSO against aerobic plate count $(A P C)$ in model food matrix

For the first 4 weeks, no significant differences (the f-ratio value is 0.721 ; the p-value is 0.499787 ) were noticed between treatment groups of cheeses in terms of APC (Figure 4). Nevertheless, for the last two weeks of (Day 28 - Day 42), the difference in LAB counts was significant between treatment groups (the f-ratio value is 15.03183; the p-value is 0.027331). By the $42^{\text {nd }}$ day, the reduction in APC reached $2 \log$ $\mathrm{CFU} / \mathrm{g}$ for $0.2 \% \mathrm{w} / \mathrm{w} \mathrm{NSSO}$ and only $1 \mathrm{log} \mathrm{CFU} / \mathrm{g}$ for control. These findings are different from all the other similar studies which report insignificant inhibitory action of NSSO against total bacterial count (APC). Since APC is inextricably linked to the hygiene level, these findings reveal a positive effect of NSSO on the microbiological quality by significantly reducing microbial load at the end of the study.

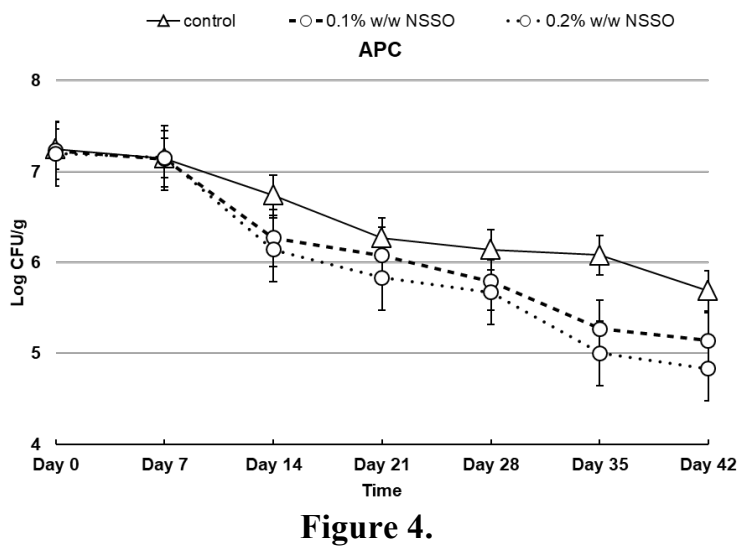

Aerobic plate count (APC) in food matrix samples over 42 days (enriched with $0.1 \%$ and $0.2 \% \mathrm{w} / \mathrm{w}$

NSSO, compared with control cheese)

Antimicrobial effect of NSSO against naturally occurring lactic acid bacteria (LAB) in model food matrix

There are numerous studies which report analysis of the particular lactic acid bacteria of similar food matrices, indicating the importance of this natural set of starting bacteria, which is strongly associated with the quality of these foods [18]. Naturally occurring lactic acid bacteria (LAB) are considered essential competitors for the pathogenic microorganisms throughout ripening, so any natural additive should not induce $\mathrm{LAB}$ inhibition along with pathogen inhibition. Natural LAB garnish have been reported to present special adaptive features to the environment and to local pathogens, including bacteriophage [36]. Therefore, no artificial LAB enrichment was done and results still revealed high counts of $\mathrm{LAB}$ in all 
FARMACIA, 2018, Vol. 66, 6

treatment samples $(6.74-6.83 \log \mathrm{CFU} / \mathrm{g})$. No significant differences were noticed between cheese treatments in terms of LAB counts throughout the study length $(p<0.05)$ (Figure 5), which is in agreement with the findings reported by other authors [55]. Similar selective antimicrobial activity which does not interfere with lactobacilli, lactococci and enterococci, but induces inhibition of pathogenic bacteria, was reported for Nigella sativa seeds added to cheese [72].
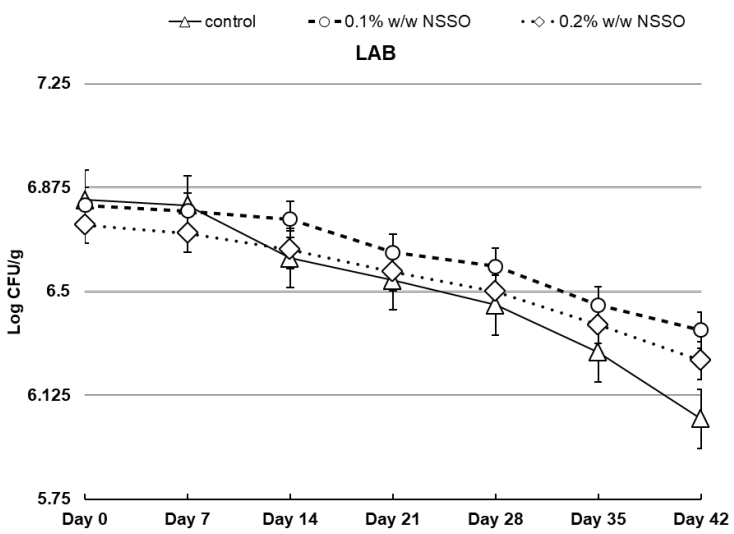

Figure 5.

Lactic acid bacteria (LAB) count in experimental food matrix samples over 42 days (enriched with $0.1 \%$ and $0.2 \% \mathrm{w} / \mathrm{w} \mathrm{NSSO}$, compared with control cheese)

The impact of this research is given by the findings related to the selective antimicrobial activity of NSSO, in the particular context of the study protocol, which focuses on evaluating the functional effect of NSSO in traditionally made cheese, without additives such as starter cultures and without pathogen cultures addition. This natural microbiological environment with high specificity may imply a certain degree of contaminant bacteria resistance to antimicrobial solutions on one hand, and to the natural LAB, on the other hand. Therefore, the efficiency of NSSO as antimicrobial agent against the natural contaminating wild strains of staphylococci, E. coli and coliforms is especially relevant considering the simultaneous keeping of natural LAB at considerable high levels throughout the study length (6.04 log CFU/g LAB in control batch and $6.25 \log$ CFU/g LAB in $0.2 \% \mathrm{w} / \mathrm{w} \mathrm{NSSO}$ batch, after 42 days).

Sensory evaluation of the food matrix samples The food matrix samples enriched with NSSO scored significantly higher overall quality grades compared with control batch of food matrix (the f-ratio value is 13.68585; the $p$-value is $<0.00001$ ), with an average of $8.05 \pm 0.4501$ for control batch, $8.5 \pm 0.5547$ for $0.1 \% \mathrm{w} / \mathrm{w}$ NSSO batch and $8.625 \pm 0.5401$ for $0.2 \% \mathrm{w} / \mathrm{w}$ NSSO batch. A slight increase of overall quality scores can be noticed during the experiment for control batch samples (from $7.9 \pm 0.5676$ for fresh cheeses, to $8.2 \pm 0.4216$ for 42-day ripened cheeses), but no significance could be noticed (the f-ratio value is 0.81081 ; the p-value is 0.496261 ). For NSSO enriched batch, the overall quality seemed relatively constant, as average scores raised and dropped without an obvious pattern throughout the study.

Total scores of the cheese samples calculated according to the ratios established for the considered attributes (overall quality $40 \%$, flavour $30 \%$, body and texture $20 \%$ and appearance $10 \%$ ) indicated that there is significant difference (the f-ratio value is 35.69971; the p-value is 0.000053 ) in perception of the panellists in the total quality of the cheese enriched with NSSO, in comparison with the control samples (Table I). The cheeses with $0.2 \% \mathrm{w} / \mathrm{w}$ NSSO scored the highest grade $(85.9 \pm 1.0033)$, followed by $0.1 \% \mathrm{w} / \mathrm{w}$ NSSO cheeses $(83.6 \pm 0.7438)$, while control cheeses scored the lowest grade $(80.375 \pm 1.0144)$. The scores appear to slightly improve over the study length, for all cheese samples, as indicated by data in Table I, but there was no statistical significance to this matter (The f-ratio value is 0.2464 ; the $p$-value is 0.861691$)$. These findings are in agreement with our previous research [35], which indicated that the most appropriate NSSO concentration for food matrix supplementation ranges within $0.05-0.2 \% \mathrm{w} / \mathrm{w}$.

Table I

Total average scores of sensory attributes

\begin{tabular}{|c|c|c|c|}
\hline TOTAL & control & $0.1 \% \mathrm{w} / \mathrm{w}$ NSSO & $0.2 \% \mathrm{w} / \mathrm{w}$ NSSO \\
\hline Fresh & 78.9 & 82.6 & 85.4 \\
\hline Day 14 & 80.6 & 83.5 & 85 \\
\hline Day 28 & 80.8 & 84.3 & 85.9 \\
\hline Day 42 & 81.2 & 84 & 87.3 \\
\hline Average score & 80.375 & 83.6 & 85.9 \\
\hline SD & 1.014478 & 0.7438637 & 1.003327 \\
\hline
\end{tabular}

Functional evaluation of NSSO enrichment effect on the physicochemical properties of the food matrix The titratable acidity did not reveal significant differences among experimental cheese batches (the f-ratio value is 1.17149 . The p-value is 0.342965 ), even though the average values of triplicates were lower for $0.1 \% \mathrm{w} / \mathrm{w}$ NSSO $(0.57 \pm 0.1268 \%$ lactic acid $)$ and $0.2 \% \mathrm{w} / \mathrm{w}$ NSSO $(0.52 \pm 1.3896 \%$ lactic acid $)$ cheeses, compared with control cheeses $(0.64 \pm 0.1501 \%$ lactic acid) (Figure 6). The $\mathrm{pH}$ values were consistent with the titratable acidity, following a decreasing trend (Figure 7). However, no statistical significance could 
FARMACIA, 2018, Vol. 66, 6

be associated with this trend (the f-ratio value is 0.54613 ; the $\mathrm{p}$-value is 0.703448 ).

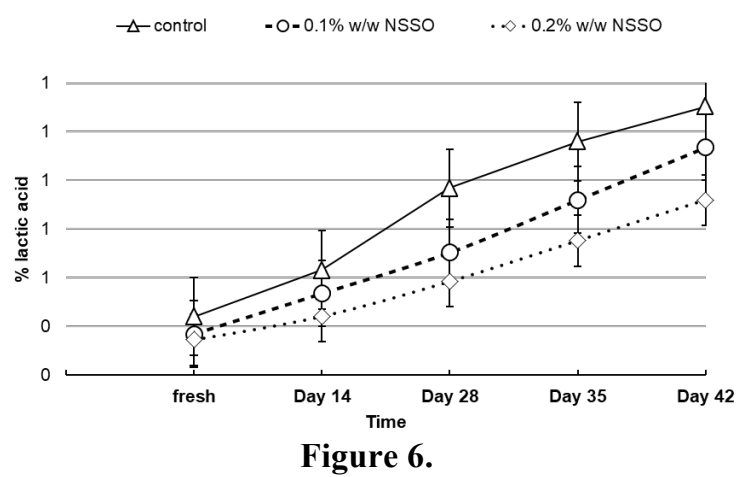

Titratable acidity values for experimental food matrix model

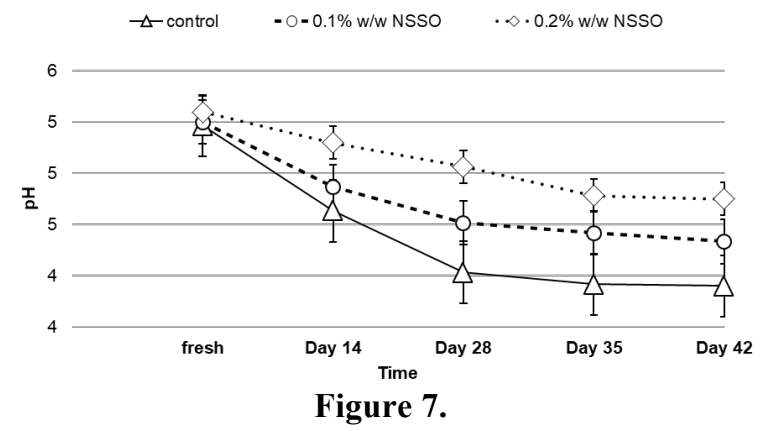

$\mathrm{pH}$ trend over time for experimental food matrix samples (values are the mean of duplicate measuring

for each sample by two measuring methods)

The data presented for titratable acidity and $\mathrm{pH}$ trends are similar to those reported by the literature [55]. However, in other studies, gradual increase of $\mathrm{pH}$ values during brine ripening, associated with a gradual decrease of titratable acidity, were reported [53], but those differences were explained by yeast metabolic activity. The $\mathrm{pH}$ decrease is an important factor in the limitation of E. coli and coliforms development and this is a positive aspect in food ripening. Nevertheless, even if no significance could be associated, the data shows slightly lower values of $\mathrm{pH}$ for NSSO enriched food matrix samples, which is worth further studying for establishing if there is a cause-effect relationship between $\mathrm{pH}$ decrease and NSSO.

No significant differences in moisture content were noticed between treatment groups of cheeses (the fratio value is 0.76808 ; the $p$-value is 0.476501 ), even though results indicated higher average values for NSSO added cheeses $(56.43 \pm 0.6065$ for $0.1 \% \mathrm{w} / \mathrm{w}$ NSSO and $56.49 \pm 0.3312$ for $0.2 \% \mathrm{w} / \mathrm{w} \mathrm{NSSO}$, compared with $53.19 \pm 0.0907$ for control, at 42 days). Although data indicates moisture loss during the experiment, which is consistent with most literature findings [44], no statistical significance could be associated to the trends of moisture decrease (the fratio value is 0.76808 ; the $p$-value is 0.476501 ), unlike other sources which communicated $\mathrm{p}$ values $<0.05$ for moisture decrease findings [55]. Moreover, most authors report lower moisture values for similar type cheeses throughout processing and ripening [46]. This might be explained by not using calcium chloride, nor starter culture in cheese manufacturing and by using lower brine concentrations than those reported by the literature $[56,58,63]$. However, the slightly higher moisture values for the NSSO added cheeses are consistent with the sensory evaluation findings which revealed slightly higher scores of body and texture for the $0.2 \% \mathrm{w} / \mathrm{w} \mathrm{NSSO}$ cheese in comparison with control. In terms of sensory quality, it seems that there is a positive association (results at threshold of statistical significance, $\mathrm{p}=0.05$ ) between NSSO and higher water content, as $0.2 \% \mathrm{w} / \mathrm{w}$ NSSO might prevent loss of body and texture during food storage. The fat and protein content of analysed cheeses revealed similar values for control cheeses and NSSO cheeses, as no significant differences were noticed within the three treatment groups $(p>0.05)$. The trends of fat content increase with the ripening are commonly cited by literature [78] and are related to the moisture loss and non-fat dry matter decrease, following protein breakdown and whey loss. Also, the lower values of protein content of NSSO enriched samples, compared to control suggest a positive influence of NSSO on cheese proteolysis. This is also cited in literature, some studies implying that NSSO association with more intense proteolysis leads to the formation of aldehydes, ketones and other miscellaneous compounds [22] which correlate to a higher acceptance of these cheeses to consumers.

Results of physicochemical properties of NSSO enriched food matrix samples revealed no significant $(p>0.05)$ differences between treated cheeses and control, even though data indicates slightly better moisture retention, higher proteolysis and almost similar fat content after 42 days which are consistent with better sensory grades awarded by panellists. These results indicate that $0.1-0.2 \% \mathrm{w} / \mathrm{w}$ NSSO does not interfere in a negative way with the biochemical characteristics of ripening process and actually improves consumers' acceptability and water retention.

These results indicate a significant better consumer acceptance of NSSO enriched food matrices in comparison with control, unlike other studies which reported no significant differences between sensory attributes of NSSO-treated cheeses and control cheeses [26]. Our results are similar to those reported by [22], who stated that Nigella sativa improved sensory scores and proteolysis of raw sheep's milk cheese. However, other studies, using Nigella sativa seeds instead of cold pressed oil, indicate that higher concentration of seeds decreases sensory attributes of cheeses, resulting in darker shades of colour and unpleasant bitter taste [59], along with significant dry matter and fat content decrease [72]. 


\section{Conclusions}

E. coli, coliforms and Staphylococcus were significantly inhibited by NSSO, while APC only showed significant lower counts for the last two weeks of the study. The antimicrobial activity of NSSO proved selective, as no significant effect was seen on LAB, which is extremely beneficial since LAB play an important role in keeping microflora balance throughout the experiment. NSSO significantly improved the sensory qualities of the experimental food matrix. Both $\mathrm{pH}$ and titratable acidity follow dynamics considered beneficial for pathogen inhibition and are not affected by NSSO enrichment of the food matrix. This study shows that NSSO remains an efficient antimicrobial solution even when used in complex, dynamic food matrices. The interaction with the complex microbiological ecosystem of the food matrix leads to selective inhibition of pathogens, with no significant interference with the beneficial lactic acid microorganisms. These results suggest that NSSO keeps efficient antimicrobial effect even when used in natural food matrices, which makes it a strong natural antibiotic candidate that could be used as food dietary supplement.

\section{References}

1. Abdel-Razig KA, Kunna MA, Ala Siddig M, Effect of levels of black cumin seeds (Nigella sativa) and storage period on biochemical properties and acceptability of Sudanese braided cheese. Sudanese J Agric Sci., 2013; 1: 55-62.

2. Abedi AS, Rismanchi M, Shahdoostkhany M, Mohammadi A, Mortazavian AM, Microwave-assisted extraction of Nigella sativa L. essential oil and evaluation of its antioxidant activity. J Food Sci Technol., 2017; 54(12): 3779-3790.

3. Ahmad A, Husain A, Mujeeb M, Khan SA, Najmi AK, Siddique NA, A review on therapeutic potential of Nigella sativa: A miracle herb. As Pac J Trop Biomed., 2013; 3(5): 337-352.

4. Alsawaf SD, Alnaemi HS, Effect of Nigella sativa (seed and oil) on the bacteriological quality of soft white cheese. Iraqi J Vet Sci., 2011; 25(1): 21-27.

5. Alzahraa MID, Physicochemical Properties, Bioactive Compounds and Antioxidant Activity of Kareish Cheese Fortified with Spirulina platensis. World J Dairy Food Sci., 2017; 12(2): 71-78.

6. Amatiste S, Sagrafoli D, Giacinti G, Rosa G, Carfora V, Marri N, Antimicrobial Activity of Essential Oils Against Staphylococcus aureus in Fresh Sheep Cheese. It J Food Safety, 2014; 3(3): 1696.

7. ANOVA, version 9.1. SAS institute Inc., Cary, USA, 2003. One way analysis of variance using SAS, www.socscistatistics.com/tests/anova.

8. AOAC Official Method 2003.08. Staphylococcus aureus in selected dairy foods. Gaithersburg, MD, USA, AOAC International, 2003.

9. AOAC Official Method 33.7.12A - Determination of Nitrogen (Total) in cheese. Kjeldahl Method. AOAC International, 2003.
10. AOAC Official Method 926.08, sec 33.7.03. Vacuum oven moisture analysis in cheese.

11. AOAC Official Method 986.33 and 989.10. Aerobic Plate Count System determination, AOAC, Washington DC, $15^{\text {th }}$ ed., AOAC, Arlington, Virginia, 1990.

12. AOAC Official Methods 933.05. Fat in Cheese petroleum ether extraction; Official Methods of Analysis, $16^{\text {th }}$ Ed., AOAC INTERNATIONAL, Gaithersburg, MD, 1987.

13. AOAC Official Methods 986.33 and 989.10. Enumeration of coliforms in milk, raw milk and dairy products.

14. AOAC Official Methods of Analysis Chemists, Titratable acidity of cheese. Association of Official Analytical Chemists, $15^{\text {th }}$ ed., AOAC, USA, Virginia, Arlington, 1990.

15. Bakal SN, Bereswill S, Heimesaat MM, Finding Novel Antibiotic Substances from Medicinal Plants - Antimicrobial Properties of Nigella sativa Directed against Multidrug-resistant Bacteria. Eur J Microbiol Immunol. (Bp), 2017; 7(1): 92-98.

16. Bakathir HA, Abbas NA, Detection of the Antibacterial Effect of Nigella sativa Ground Seeds with Water. Af J Tradit Complement Alt Med., 2011; 8(2): 159-164.

17. Barbuceanu F, Popovici A, Diaconu C, Hotoiu C, Stamate D, Raita S, Denişan DD, Predoi G, Histological researches on assessment of some staining histological methods used for diagnosis of bovine tuberculosis. Sci Works C (Vet Med, Bucharest), 2013; Series LIX: 20093098074.

18. Begovic J, Brandsma JB, Jovcic B, Tolinacki M, Veljovic K, Meijer W, Analysis of dominant lactic acid bacteria from artisanal raw milk cheeses produced on the mountain Stara Planina, Serbia. Arch Biol Sci., 2011; 63(1): 11-20.

19. Bernini V, De Dea Lindner J, Gatti M, De Lorentiis A, Bottari B, Santarelli M, Microbial Dynamics During Parmigiano Reggiano Cheese Production and Ripening, Book of abstracts of The $5^{\text {th }}$ IDF symposium on cheese ripening, 9-13 March 2008; 102.

20. Bianchi DM, Gallina S, Bellio A, Chiesa F, Civera T, Decastelli L, Enterotoxin gene profiles of Staphylococcus aureus isolated from milk and dairy products in Italy. Lett Appl Microbiol., 2014; 58(2): 190-196.

21. Bintsis T, Papademas P, Microbiological quality of white-brined cheeses: A review. Int J Dairy Tech., 2002; 55: 113-120.

22. Cakir Y, Cakmakci S, Hayaloglu AA, The effect of addition of black cumin (Nigella sativa L.) and ripening period on proteolysis, sensory properties and volatile profiles of Erzincan Tulum (Şavak) cheese made from raw Akkaraman sheep's milk. Small Ruminant Res., 2016; 134: 65-73.

23. Choi $\mathrm{KH}$, Cheese microbial risk assessments - A review. Asian-Australasian J Animal Sci., 2016; 29: 307-314.

24. Cooper IR, A review of current methods using bacteriophages in live animals, food and animal products intended for human consumption. J Microbiol Met., 2016; 130: 38-47.

25. Dajani EZ, Shahwan TG, Dajani NE, Overview of the preclinical pharmacological properties of Nigella sativa (black seeds): a complementary drug with historical and clinical significance. J Physiol Pharmacol., 2016; 67(6): 801-817. 
FARMACIA, 2018, Vol. 66, 6

26. Delbes C, Alomar J, Chougui N, Martin JF, Montel $\mathrm{MC}$, Staphylococcus aureus growth and enterotoxin production during the manufacture of uncooked, semihard cheese from cows' raw milk. J Food Prot., 2006; 69(9): 2161-2167.

27. Eck A, Gillis JC, Cheese making - From science to quality assurance, $2^{\text {nd }}$ edition, translated by Gaelle Davies, Intercept Ltd., 2004.

28. El-Dahma MM, Khattab AA, Gouda E, El-Saadany KM, Ragab WA, The Antimicrobial Activity of Chitosan and Its Application on Kariesh Cheese Shelf Life. Alexandria Sci Exchange J: An Int Quarterly J of Sci Agric Environ., 2017; 38: 733-745.

29. Emeka LB, Emeka PM, Khan TM, Antimicrobial activity of Nigella sativa L. seed oil against multidrug resistant Staphylococcus aureus isolated from diabetic wounds. Pak J Pharm Sci., 2015; 28(6): 1985-1990.

30. Fadavi A, Beglaryan R, Optimization of UF-Feta cheese preparation, enriched by peppermint extract. J Food Sci Tech., 2015; 52(2): 952-959.

31. Forouzanfar F, Bazzaz BSF, Hosseinzadeh H, Black cumin (Nigella sativa) and its constituent (thymoquinone): a review on antimicrobial effects. Ir J Basic Med Sci., 2014; 17(12): 929-938.

32. Fox PF, Guinee TP, Cogan TM, McSweeney PLH, Fundamentals of cheese science, An Aspen Publication Inc., Gaithersburg, Maryland, USA, 2000; 19-43, 206-278, 388-429, 484-514.

33. Gao ML, Hou HM, Teng XX, Zhu YL, Hao HS, Microbial diversity in raw milk and traditional fermented dairy products (Hurood cheese and Jueke) from Inner Mongolia, China. Genet Mol Res., 2017; 16(1): 1-13.

34. Gatti M, De Dea Lindner J, Turroni F, Cavatorta V, Sforza S, Dossena A, Microbiological and Proteolytic Aspects of Parmigiano Reggiano Cheese Ripening, Book of abstracts of The $5^{\text {th }}$ IDF symposium on cheese ripening, 9-13 March 2008; Bern, Switzerland: 53.

35. Georgescu D, Georgescu M, Tapaloaga D, Raita S, Sensory evaluation of experimental soft cheese enriched with Nigella sativa seed oil used as natural enhancer. J Biotech., 2018; 280: S58.

36. Georgescu M, Dobrea M, Georgescu D, Microbial Population Dynamics in Presence of Lactococcal Bacteriophage During Ripening of Traditional Raw Milk Romanian Cheese. Agric Agric Sci Proced., 2015; 6: 324-331.

37. Georgescu M, Dobrea M, Tapaloaga D, Raita S,, Dobrea V, Functional evaluation of Nigella sativa seed oil effect on pathogen enriched Artisan cheese. J Biotech., 2018; 280: S54.

38. Grigoraş AG, Dunca SI, Ochiuz L, Evaluation of antibacterial activity of two poly-(carboxybetaines) derived from poly(4-vinylpyridine). Farmacia, 2017; 65(1): 104-108.

39. Gholamnezhad Z, Havakhah S, Boskabady MH, Preclinical and clinical effects of Nigella sativa and its constituent, thymoquinone: A review. J Ethnopharmacol., 2016; 190: 372-386.

40. Gouvea FS, Rosenthal A, Ferreira HER, Plant extract and essential oils added as antimicrobials to cheeses: a review. Ciência Rural, 2017; 47(8): e20160908: 1-9.

41. Hajhashemi V, Ghannadi A, Jafarabadi H, Black cumin seed essential oil, as a potent analgesic and antiinflammatory drug. Phytother Res., 2004; 18(3): 195-199.

42. Hannan A, Saleem S, Chaudhary S, Hussain M, Usman Arshad M, Anti bacterial activity of Nigella sativa against clinical isolates of methicillin resistant Staphylococcus aureus. J Ayub Med College (Abbottabad), 2008; 20: 72-74.

43. Hasan NA, Nawahwi MZ, Malek HA, Antimicrobial activity of Nigella sativa seed extract. Sains Malaysiana, 2013; 42(2): 143-147.

44. Hasanzadeh A, Raftani A, Aminifar M, Changes in the physicochemical, microstructural and rheological properties of traditional Kope cheese during ripening. Int J Dairy Technol., 2018; 71(2): 347-355.

45. Hassanien MFR, Assiri AMA, Alzohairy AM, Oraby HF. Health-promoting value and food applications of black cumin essential oil: an overview. J Food Sci Tech., 2015; 52(10): 6136-6142.

46. Hassanien MFR, Mahgoub SA, El-Zahar KM, Soft cheese supplemented with black cumin oil: Impact on food borne pathogens and quality during storage. Saudi J Bio Sci., 2014; 21(3): 280-288.

47. IDF Factsheet 001/2017-03. Special Issue of the Int. Dairy Federation SI-1401, 2014. The Importance of salt in the manufacture and ripening of cheese.

48. Ijaz H, Tulain UR, Qureshi J, Danish Z, Musayab S, Akhtar MF, Nigella sativa (Prophetic Medicine): A Review. Pak J Pharm Sci., 2017; 30(1): 229-234.

49. Isaconi IV, Constantinescu CM, Raita S,, Gagniuc E, Militaru M, The relevance of histopathological examination in the evaluation of processed meat products. J Biotech., 2018; 280: S54-S55.

50. ISO 4121/2003 - Sensory analysis - Guidelines for the use of quantitative response scale. Geneva, Switzerland: International Organization for Standardization (ISO); 2003.

51. Kav K, Col R, Ardic M, Characterization of Staphylococcus aureus isolates from white-brined Urfa cheese. J Food Prot., 2011; 74(11): 1788-1796.

52. Kraggerud H, Solem S, Abrahamsen RK, Quality scoring - A tool for sensory evaluation of cheese?. Food Quality and Preference, 2012; 26(2): 221-230.

53. Levkov V, Srbinovska S, Gjorgovska N, Microbiological and chemical characteristics of traditional ewe's milk cheese from Mariovo region. Mljekarstvo, 2014; 64(3): 195-206.

54. Little CL, Rhoades JR, Sagoo SK, Harris J, Greenwood M, Mithani V, Microbiological quality of retail cheeses made from raw, thermized or pasteurized milk in the UK. Food Microbiology, 2008; 25: 304-312.

55. Mahgoub SA, Ramadan MF, El-Zahar KM, Cold Pressed Nigella sativa Oil Inhibits the Growth of Foodborne Pathogens and Improves the Quality of Domiati Cheese. J Food Safety, 2013; 33: 470-480.

56. Marino M, Innocente N, Maifreni M, Mounier J, Cobo-Díaz JF, Coton E, Diversity within Italian Cheese making Brine-Associated Bacterial Communities Evidenced by Massive Parallel 16S rRNA Gene Tag Sequencing. Front Microbiol., 2017; 8: 2119: 1-13.

57. Mercanoglu Taban B, Akineden O, Karimihachehsoo S, Gross M, Usleber E, Enterotoxigenic Staphylococcus aureus in brined cheese from weekly street markets in Ankara, Turkey. J Food Safety and Food Quality, 2017; 68(5): 117-123. 
FARMACIA, 2018, Vol. 66, 6

58. Mestani M, Ramadani X, Gjergji TM, Dizdarevic $\mathrm{T}$, Mehmeti I, Influence of Brine Concentration and Ripening Temperature on Quality of Sharri Cheese. Int J Dairy Sci., 2017, 12: 310-317.

59. Mohamed F Ramadan, Chapter 30 - Black Cumin (Nigella sativa) Oils, In Essential Oils in Food Preservation, Flavor and Safety, edited by Preedy VR, Academic Press, San Diego, 2016; 269-275.

60. Muhammet A, Osman S, Umit G, Antibacterial effect of Turkish black cumin (Nigella sativa L.) oils. Grasas y Aceites, 2005; 56(4): 259-262.

61. Nicolaescu M, Research concerning the hygienicsanitary quality of some traditional Romanian cheeses and the food safety - public health implications [PhD Thesis]. Bucharest, Romania: 2008, available in Romanian.

62. Öner Z, Karahan AG, Aloglu H, Changes in the microbiological and chemical characteristics of an artisanal Turkish white cheese during ripening. Elsevier Sci Direct, 2006; 39: 449-454.

63. Pappas CP, Kondyli E., Voutsinas LP, Heleni M, Effects of salting method and storage time on composition and quality of Feta cheese. Int J Dairy Tech., 2007; 49: 113-118.

64. Pimentel TC, Gomes da Cruz A, Deliza R, Sensory Evaluation: Sensory Rating and Scoring Methods. Encyclopedia of Food and Health, 2016; 744-749.

65. Prates Denise da Fontoura, Würfel SR, Goldbeck JC, Lima ASL, Graciela V, Silva WP, Microbiological quality and safety assessment in the production of moderate and high humidity cheeses. Ciência Rural, 2017; 47(11): 1-6.

66. Rafati S, Niakan M, Naseri M, Anti-microbial effect of Nigella sativa seed extract against staphylococcal skin Infection. Med J Islam Rep Iran, 2014; 28: 42.

67. Raita ȘM, Cornilă N, Danacu V, Roșu P, Barbuceanu F, Histological researches concerning the pancreas in Struthio camelus Anatomia, Histologia, Embryologia. Blackwell Verlag GmbH Ana Histol Embryol., 2014; 43(Suppl. 1): 74-75.

68. Raita ȘM. Histological and Histochemical Study on the Tongue Structure to Ostrich. The $6^{\text {th }}$ Anniversary Symposium of National Animal Health and Diagnostic Institute, 11-12 October 2011, Bucharest, Book of abstracts: $138-139$.
69. Raita ȘM, Issue on the cytohistological and histochemical structure on the cecum to ostrich. Veterinary Medicine Faculty Symposium Contribution of the Scientific Research to Veterinary Medicine Progress, Bucharest, 17-28 November 2011; 48-49.

70. Suceveanu AI, Pantea Stoian A, Mazilu L, Voinea F, Hainăroșie R, Diaconu CC, Pițuru S, Nițipir C, Badiu DC, Ceauşu I, Suceveanu AP, Interferon-free therapy is not a trigger for hepatocellular carcinoma in patients with chronic infection with hepatitis $\mathrm{C}$ virus. Farmacia, 2018; 66(5): 904-908.

71. Tăpăloagă D, Milk and meat processing technologies (available in Romanian). Granada, Bucharest 2013; 255-260.

72. Tarakci Z, Ekici K, Sagdic O, Kucukoner E, The effect of black cumin on ripening of Tulum cheese. Archiv fur Lebensmittelhygiene, 2005; 56: 135-139.

73. Taerel AE, Rosenberg L, Nicolescu T, Ethics and equity in providing pharmaceutical assistance to the population. Revista Romana de Bioetica, 2010; 8(1): 150-154.

74. Utami AT, Pratomo B, Study of Antimicrobial Activity of Black Cumin Seeds (Nigella sativa L.) Against Salmonella typhi In Vitro. J Med Surg Pathol., 2016; 1: 127.

75. Uzair B, Hameed A, Nazir S, Ali Khan B, Fasim F, Khan S, Synergism Between Nigella sativa Seeds Extract and Synthetic Antibiotics Against Mec A Gene Positive Human Strains of Staphylococcus aureus. Int J Pharmacology, 2017; 13: 958-968.

76. Wahba NM, Ahmed AS, Ebraheim ZZ, Antimicrobial effects of pepper, parsley, and dill and their roles in the microbiological quality enhancement of traditional Egyptian Kareish cheese. Foodborne Pathog Dis., 2010; 7(4): 411-418.

77. Wolfe BE, Dutton RJ, Towards an Ecosystem Approach to Cheese Microbiology. Microbiol Spectr., 2013; 1(1): 1-9.

78. Zahra M, Thompson CS, Tallua K, Application of Liposomes in the Food Industry (Chapter 13). In: Anilkumar G., Vasisht GN, Khare AR, Sobel R, editors. Microencapsulation in the Food Industry A Practical Implementation Guide, 2014; 139-150. 